KALAMATIKA Jurnal Pendidikan Matematika Volume 2, No. 2, November 2017, hal. 159-176

\title{
KESULITAN SISWA BERPIKIR ABSTRAK MATEMATIKA DALAM PEMBELAJARAN PROBLEM POSING BERKELOMPOK
}

\author{
Iik Nurhikmayati \\ Universitas Majalengka \\ ik.nurhikmayati@gmail.com
}

\begin{abstract}
ABSTRAK
Penelitian ini didasarkan adanya kesulitan siswa berpikir abstrak pada materi bangun ruang. Masih banyak siswa yang merasa bingung manakala harus membayangkan kemudian menggambarkan setiap objek bangun ruang karena pada dasarnya materi bangun ruang banyak menggunakan visualisasi model matematika yang secara konkret tidak nyata dan tidak selalu ada dalam kehidupan sehari-hari. Kesulitan tersebut menyebabkan siswa tidak dapat menyelesaikan persoalan-persoalan pada materi bangun ruang. Hal ini menggambarkan masih rendahnya kemampuan abstraksi matematis siswa. Salah satu metode pembelajaran yang dapat meningkatkan kemampuan abstraksi matematis adalah pembelajaran problem posing berkelompok. Tujuan penelitian ini adalah (1) mendeskripsikan kesulitan siswa berpikir abstrak matematika dalam pembelajaran problem posing berkelompok; (2) mengetahui faktor-faktor yang menyebabkan kesulitan siswa berpikir abstrak matematika dalam pembelajaran problem posing berkelompok. Penelitian ini menggunakan penelitian dengan pendekatan kualitatif dan bersifat deskriptif. Subyek penelitian ini adalah siswa-siswa kelas X yang berjumlah 36 siswa. Instrumen yang digunakan dalam penelitian ini adalah soal tes kemampuan abstraksi matematis, angket serta pedoman wawancara. Hasil penelitian menunjukkan masih banyak siswa yang mengalami kesulitan berpikir abstrak matematika dalam pembelajaran problem posing berkelompok diantaranya adalah (1) siswa kurang penguasaan konsep; (2) siswa tidak melakukan pengalaman langsung dengan objek; (3) siswa kurang mampu mengaplikasikan konsep pada konteks yang sesuai; dan (4) siswa mengalami kesulitan dalam memanipulasi objek matematis yang abstrak. Sedangkan faktor-faktor yang menyebabkan siswa sulit berpikir abstrak berasal dari faktor ekstern yaitu minimnya penggunaan media alat peraga dalam pembelajaran.
\end{abstract}

Kata Kunci : Berpikir Abstrak Matematika, Kesulitan Belajar, Problem Posing Berkelompok

\begin{abstract}
This study was based on the difficulty of students to think abstractly in the material geometry. There are still many students who feel confused when should imagine and then describe each object geometry because basically a lot of material geometry using visualization mathematical model that concretely not real and do not always exist in everyday life. The difficulties caused students cannot resolve the problems on the material geometry. This illustrates the poor ability of students' mathematical abstraction. One of the methods that can improve the ability of mathematical abstraction is a problem posing learning groups. The purpose of this study is (1) to describe the difficulty of students of abstract mathematical thinking in problem posing learning groups; (2) determine the factors that cause difficulty in abstract mathematical thinking in problem posing learning groups. This study used a descriptive qualitative research approach. The subjects of this study are students of grade X with 36
\end{abstract}


students. The instrument used in this study is mathematical abstraction ability tests, questionnaires and interview guidelines. The results showed there are still many students who have difficulty in abstract mathematical thinking in problem posing learning groups which are (1) students lack mastery of concepts; (2) the student does not perform direct experience with the object; (3) students are less able to apply the concept in an appropriate context; and (4) students have difficulty in manipulating abstract mathematical object. While the factors that lead to difficult students to think abstractly derived from external factors, namely the lack of media use props in learning.

Keywords: Abstract Mathematical Thinking, Learning Difficulties, Problem Posing in Groups

Format Sitasi: Nurhikmayati, I. (2017). Kesulitan Siswa Berpikir Abstrak Matematika dalam Pembelajaran Problem Posing Berkelompok. KALAMATIKA Jurnal Pendidikan Matematika. 2(2), 159-176.

Penyerahan Naskah: 4 Juli 2017 || Revisi: 27 Juli 2017 || Diterima: 1 Agustus 2017

\section{PENDAHULUAN}

Berpikir merupakan salah satu aktivitas utama dalam sebuah pembelajaran. Dengan berpikir maka siswa akan mampu mencapai keberhasilan dalam sebuah pembelajaran. Proses berpikir dalam pembelajaran matematika dikenal dengan kemampuan berpikir matematis. Berpikir matematis dapat memudahkan terbentuknya keterampilan belajar matematika dengan baik dan memungkinkan tercapainya tujuan pendidikan matematika.

Kemampuan berpikir matematis sudah selayaknya dimiliki oleh setiap siswa. Hal ini dikarenakan kemampuan berpikir matematis merupakan kunci utama dalam belajar matematika. Dengan kemampuan tersebut maka siswa dapat menyelesaikan setiap persoalan matematika yang diberikan. Menurut Sumarmo (2010), istilah berpikir matematis dapat diartikan sebagai cara berpikir berkenaan dengan proses matematika (doing math) atau cara berpikir dalam menyelesaikan tugas matematis (mathematical task) baik yang sederhana maupun yang kompleks. Dengan demikian untuk dapat mencapai keberhasilan belajar matematika, kemampuan berpikir matematis menjadi hal yang wajib dimiliki oleh setiap siswa di setiap jenjang pendidikan.

Proses berpikir matematika tersebut memerlukan kemampuan berpikir abstrak, hal ini dikarenakan matematika sendiri merupakan sebuah ilmu dengan objek kajian yang bersifat abstrak (Nurhasanah 2010). Matematika dikatakan abstrak karena objek atau simbol-simbol dalam matematika tidak ada dalam kehidupan nyata. Kemampuan abstraksi (berpikir abstrak) dalam matematika sangat penting karena merupakan suatu kemampuan yang dapat menggambarkan situasi/masalah dalam matematika. Operasi pada bilangan matematika juga 
merupakan suatu abstraksi. Hal ini sejalan dengan pendapat Kilpatrick, Swafford, dan Findell (2001) yaitu "... abstractions apply to a broad range of real and imagined situastions. Operation on number, such as addition and multiplication, are also abstractions."

Kemampuan abstraksi juga merupakan kemampuan untuk menggambarkan dan membayangkan benda yang secara fisik tidak selalu ada. Kemampuan ini penting dimiliki agar siswa dapat memvisualisasikan dan memanipulasi sebuah objek yang bersifat maya terutama dalam pelajaran matematika. Salah satu materi matematika yang secara konkret tidak selalu nyata adalah materi bangun ruang pada jenjang Sekolah Menengah Atas. Pada materi bangun ruang, siswa dihadapkan pada hal-hal yang secara fisik tidak ada di hadapan mereka. Siswa dituntut untuk dapat membayangkan dan menggambarkan setiap komponen ataupun sifat bangun ruang yang secara real tidak ada. Sehingga pada pelaksanaannya, siswa banyak mengalami kesulitan dalam menyelesaikan persoalan yang berkaitan dengan bangun ruang.

Kesulitan siswa dalam menyelesaikan persoalan yang berkaitan dengan bangun ruang ini tentunya tidak terlepas dari rendahnya kemampuan abstraksi yang dimiliki siswa. Siswa kurang mampu merepresentasikan gagasan matematika dalam bahasa, simbol dan model matematis. Siswa kurang mampu menerjemahkan simbol dalam sebuah permasalahan matematis. Siswa juga mengalami kesulitan dalam memanipulasi objek matematis yang abstrak Padahal hal ini penting karena merupakan salah satu indikator dari kemampuan abstraksi. Jika kemampuan abstraksi siswa pada materi bangun ruang rendah, maka kemungkinan besar siswa akan mengalami kesulitan untuk persoalan matematika yang lebih kompleks dari itu.

Kesulitan siswa dalam kemampuan abstraksi matematis ini juga dapat disebabkan kurangnya kesempatan yang diberikan guru kepada siswa untuk mengembangkan kemampuannya dalam memecahkan masalah matematis. Siswa kurang dilibatkan dalam pembentukan abstraksi matematis sehingga siswa tidak dapat memvisualisasikan simbolsimbol matematis ke dalam sebuah model matematika dengan baik.

Berdasarkan pengalaman peneliti dan hasil wawancara dengan guru bidang studi matematika di SMAN 1 Leuwimunding Majalengka dikatakan bahwa salah satu materi yang dianggap sulit pada jenjang Sekolah Menengah Atas adalah materi Bangun Ruang. Kesulitan tersebut disebabkan materi bangun ruang banyak menggunakan visualisasi model matematika yang secara konkret tidak nyata dan tidak selalu ada dalam kehidupan sehari-hari. Terkadang 
masih banyak siswa yang kebingungan manakala harus membayangkan kemudian menggambarkan setiap persoalan bangun ruang yang diberikan.

Salah satu upaya mengatasi kesulitan siswa berpikir abstraks matematika adalah penerapan pembelajaran problem posing berkelompok. Pada pembelajaran problem posing ini siswa atau kelompok siswa dituntut untuk membuat soal atau pertanyaan. Setiap kelompok siswa mengajukan soal/masalah berdasarkan informasi-informasi yang diberikan guru. Pengajuan soal/masalah secara berkelompok ini akan memacu kreativitas siswa karena dilakukan secara bersama-sama. Siswa akan saling melengkapi, memberikan pendapat/ide dan jawaban dalam setiap persoalan matematika. Menurut Upu (2003) jika soal dirumuskan secara berkelompok, maka kualitas soal yang diajukan siswa menjadi lebih baik dari aspek tingkat penyelesaiannya maupun kandungan informasinya. Artinya belajar secara berkelompok jauh lebih baik daripada belajar secara individu.

Dalam pelaksanaan pembelajaran problem posing berkelompok ini, setiap kelompok siswa diharuskan membuat soal bangun ruang dan juga harus dapat menyelesaikan soal-soal yang telah dibuat sendiri. Selain itu setiap kelompok juga akan diminta untuk mengerjakan soal-soal yang telah dibuat oleh kelompok lain. Melalui pembelajaran dengan problem posing pada materi bangun ruang inilah diharapkan siswa dapat mengembangkan kemampuan abstraksi matematis, sebab dalam aktivitas membuat soal dan menjawab sendiri soal yang dibuat, siswa akan berusaha menggali ide-ide matematika dalam pembentukan konsep berupa objek-objek matematika yang bersifat abstrak menjadi struktur baru yang lebih mudah dipahami.

Rendahnya kemampuan abstraksi matematis ini menjadi salah satu masalah dalam dunia pendidikan matematika, karena penting bagi siswa untuk memiliki kemampuan abstraksi yang tinggi untuk dapat menyelesaikan setiap persoalan matematika yang bersifat abstrak. Dengan demikian, dirasa perlu untuk dilakukan suatu pengkajian tentang kesulitan siswa dalam kemampuan abstraksi matematis khususnya pada pembelajaran problem posing berkelompok. Kajian ini dilakukan untuk dapat mengetahui letak kesulitan siswa dalam penguasaan kemampuan abstraksi matematika dengan model pembelajaran problem posing berkelompok.

Selain untuk mengetahui letak kesulitan siswa berpikir abstraks matematika pada materi bangun ruang, kajian ini juga dilakukan untuk dapat mengetahui faktor-faktor yang 
menyebabkan siswa mengalami kesulitan dalam menguasai kemampuan abstraksi matematis pada pembelajaran problem posing berkelompok.

\section{METODE PENELITIAN}

Penelitian ini menggunakan penelitian dengan pendekatan kualitatif dan bersifat deskriptif yaitu menjelaskan atau memaparkan data hasil penelitian. Penelitian ini bertujuan mendeskripsikan kesulitan siswa berpikir abstraks matematika pada pembelajaran problem posing berkelompok dan mengetahui faktor-faktor yang menyebabkan kesulitan tersebut. Penelitian ini lebih menekankan pada proses dan makna dan cenderung menggunakan analisis dengan pendekatan induktif.

Subyek penelitian ini adalah siswa-siswa kelas X IPA 1 SMAN 1 Leuwimunding Majalengka tahun ajaran 2015/2016 yang berjumlah 36 siswa. Instrumen yang digunakan dalam penelitian ini adalah soal tes kemampuan abstraksi matematis, angket dan pedoman wawancara.

Data yang diperoleh berupa hasil tes kemampuan abstraksi matematis pada materi bangun ruang dan hasil wawancara siswa. Soal tes kemampuan abstraksi matematis berjumlah 5 soal berbentuk uraian diberikan pada siswa setelah proses pembelajaran berakhir. Dari soal tes tersebut dapat diperoleh nilai tes yang dapat digunakan untuk menentukan letak kesulitan siswa dalam menyelesaikan soal materi bangun ruang dan sejauh mana kemampuan abstraksi siswa pada materi bangun ruang. Angket dapat digunakan untuk mengetahui faktor-faktor penyebab siswa mengalami kesulitan dalam menguasai materi bangun ruang selama pembelajaran dengan problem posing berkelompok berlangsung. Sedangkan wawancara digunakan untuk menelusuri kesulitan siswa secara lebih dalam tentang kemampuan abstraksi matematis siswa pada materi bangun ruang.

\section{HASIL DAN PEMBAHASAN}

Berdasarkan hasil tes kemampuan abstraksi matematis diperoleh data persentase capaian keberhasilan belajar siswa. Dari 5 soal uraian tentang bangun ruang terlihat bahwa 64\% (23 siswa) kelas X IPA 1 telah mencapai nilai kriteria ketuntasan minimal (KKM) $\geq 73$ dan 36\% (13 siswa) kelas X IPA 1 belum mencapai nilai KKM, artinya KKM $\leq 73$. Rata-rata nilai kelas adalah 70,58 dengan skor tertinggi 81 dan skor terendah 54. Untuk mengetahui letak kesulitan siswa berpikir abstrak matematika, dapat dilihat dari kesalahan-kesalahan siswa 
dalam mengerjakan soal tes kemampuan abstraksi matematis. Kesalahan yang di analisis adalah kesalahan dalam setiap langkah penyelesaian soal. Berdasarkan data hasil analisis pengerjaan siswa, kemudian dihitung persentase kesalahan untuk tiap indikator kemampuan abstraksi matematis pada materi bangun ruang. Indikator yang dipakai dalam penelitian ini adalah indikator dari penelitian Mukhtar (2013). Berikut tabel 1 adalah tabel persentase tingkat kesulitan siswa berpikir abstrak matematika.

Tabel 1. Persentase Tingkat Kesulitan Berpikir Abstrak Matematika

\begin{tabular}{llc}
\hline No Soal & \multicolumn{1}{c}{ Indikator } & Persentase (\%) \\
\hline 1 & $\begin{array}{l}\text { Merepresentasikan gagasan matematika dalam bahasa dan } \\
\text { simbol }\end{array}$ & $16,7 \%$ \\
2 & $\begin{array}{l}\text { Mengidentifikasi karakteristik objek yang dimanipulasi atau } \\
\text { diimajinasikan }\end{array}$ & $66,7 \%$ \\
3 & Mengaplikasikan konsep pada konteks yang sesuai & $58,3 \%$ \\
4 & $\begin{array}{l}\text { Membuat hubungan antarproses atau konsep untuk } \\
\text { membentuk suatu pengertian }\end{array}$ & $30,6 \%$ \\
\hline
\end{tabular}

Berdasarkan persentase tingkat kesulitan berpikir abstrak pada table 1, dapat dilihat bahwa sebagian besar siswa masih mengalami kesulitan berpikir abstrak matematika dalam pembelajaran problem posing berkelompok. Tingkat kesulitan yang paling tinggi ada pada indikator soal nomor 5 yaitu melakukan manipulasi objek matematis yang abstrak dengan persentase tingkat kesulitan 72,2\%. Dari 36 siswa hanya 10 siswa yang mampu menjawab soal dengan nilai lebih dari rata-rata per indikator. Indikator kemampuan abstraksi matematis yang paling sulit kedua adalah indikator soal nomor 2 yaitu mengidentifikasi karakteristik objek yang dimanipulasi atau diimajinasikan sebesar 66,7\%. Dari 36 siswa terdapat 12 siswa yang mampu menjawab soal dengan benar. Selanjutnya indikator yang sulit adalah pada soal nomor 3 yaitu mengaplikasikan konsep pada konteks yang sesuai sebesar 58,3\%. Terdapat 15 siswa dari 36 siswa yang dapat menjawab dengan benar.

Berikut ini deskripsi analisis kesulitan yang dialami siswa dalam berpikir abstrak matematika dalam pembelajaran problem posing berkelompok berdasarkan hasil tes yaitu:

1. Kesulitan siswa dalam mengidentifikasi karakteristik objek yang dimanipulasi atau diimajinasikan. Soal Nomor 2 yaitu Dari puncak sebuah menara $P$, seseorang melihat dua buah titik $R$ dan $S$ yang terletak pada bidang lantai horizontal. Jarak antara titik $R$ dan $S$ adalah $15 \mathrm{~m}$. Titik $Q$ adalah proyeksi titip $P$ pada bidang lantai. Jarak $Q R=8 m, Q R \perp R S$, dan $\angle P S Q=60^{\circ}$. Dengan menggunakan data tersebut, hitunglah:

a. Jarak QS

b. Jarak PS 


\section{c. Tinggi Menara $P Q$}

Kesulitan siswa dalam menyelesaikan soal nomor 2 terletak pada sketsa gambar yang dibuat salah. Seharusnya sketsa gambar berdimensi tiga bukan berdimensi dua seperti terlihat pada lembar jawaban siswa gambar 1 berikut.

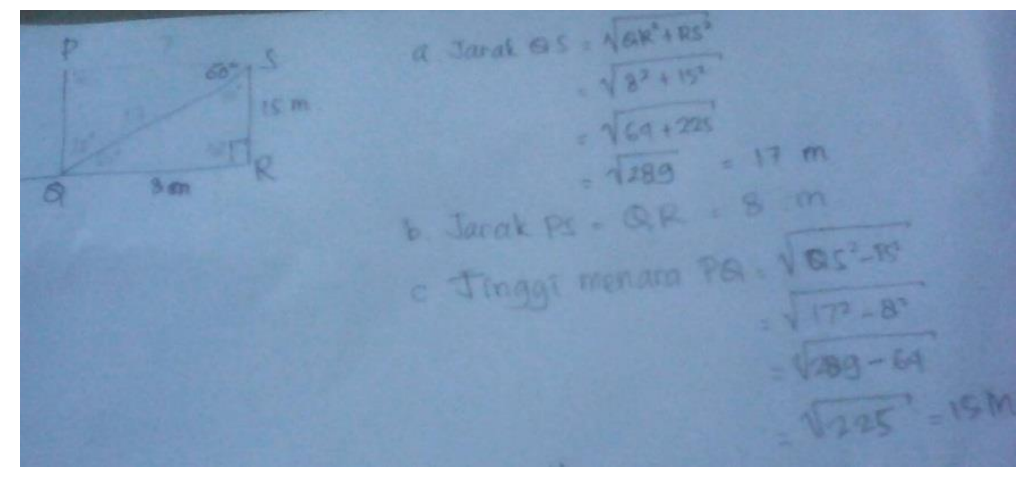

Gambar 1. Kesalahan Jawaban Siswa Soal Nomor 2

Selain kesalahan dalam membuat sketsa gambar, dalam penyelesaian jawaban juga siswa masih mengalami kesulitan. Hal tersebut dapat dilihat dari kesalahan jawaban pada bagian (b) dan (c). Pada bagian (a) siswa sudah dapat menjawab dengan benar, namun bagian (b) siswa masih melakukan kesalahan menjawab dikarenakan siswa melihat sketsa gambar yang telah dibuatnya di awal, akibatnya jawaban pun salah. Seharusnya jarak $P S \neq Q R$, jarak PS diperoleh dari rumus cosinus pada < PSQ yaitu $\cos <60^{\circ}=\frac{Q S}{P S} \leftrightarrow \frac{1}{2}=\frac{17}{P S} \leftrightarrow P S=34 \mathrm{~m}$. Dari gambar 1 siswa menjawab soal bagian (c) dengan menggunakan teorema pythagoras sudah benar, tetapi dikarenakan jawaban (b) salah maka jawaban akhir dari soal bagian (c) juga salah. Tinggi menara sebenarnya adalah $17 \sqrt{3} \mathrm{~m}$.

2. Kesulitan siswa dalam mengaplikasikan konsep pada konteks yang sesuai. Soal Nomor 3 yaitu Kubus ABCD.EFGH dengan panjang rusuk $6 \mathrm{~cm}$.

a. Hitunglah besar $<$ (AH dengan bidang $A B C D)$

b. Jika sudut antara diagonal ruang $A G$ dengan bidang alas $A B C D$ adalah $\propto$, tentukan nilai $\sin \propto !$

Kesulitan yang dialami siswa dalam mengerjakan soal nomor 3 adalah siswa tidak mengetahui rumus menentukan sudut antara garis dengan bidang. Siswa menerapkan konsep yang tidak sesuai dengan apa yang ditanyakan. Berikut adalah salah satu contoh jawaban siswa pada soal nomor 3 pada gambar 2 . 


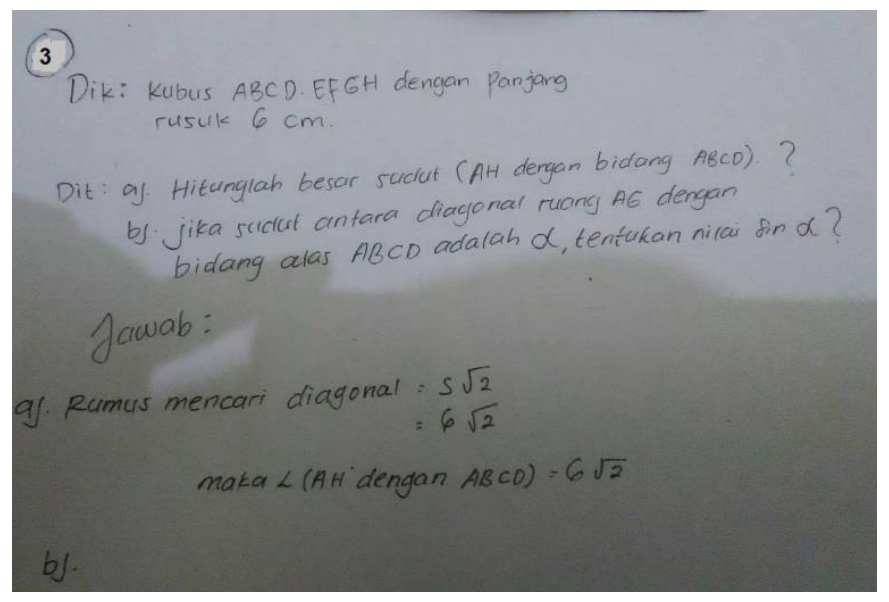

Gambar 2. Kesalahan Jawaban Siswa Soal Nomor 3

Dilihat dari hasil jawaban siswa pada soal nomor 3, dapat dipastikan bahwa siswa tersebut masih belum paham bagaimana menentukan sudut antara garis dengan bidang. Siswa menentukan sudut garis $\mathrm{AH}$ dengan bidang $\mathrm{ABCD}$ menggunakan rumus diagonal bidang. Seharusnya siswa menggambar dahulu sketsa kubus ABCD.EFGH kemudian menentukan sudut yang dibentuk oleh garis $\mathrm{AH}$ dan garis $\mathrm{AD}$ sebab $\mathrm{AD}$ adalah proyeksi $\mathrm{AH}$ pada bidang ABCD. Dengan demikian dapat ditentukan besar sudutnya yaitu $45^{\circ}$. Selanjutnya untuk soal bagian (b) siswa tidak memberikan jawaban. Hal ini menunjukkan bahwa siswa masih kesulitan dalam menyelesaikan soal nomor 3.

3. Kesulitan siswa dalam melakukan manipulasi objek matematis yang abstrak. Soal no 5

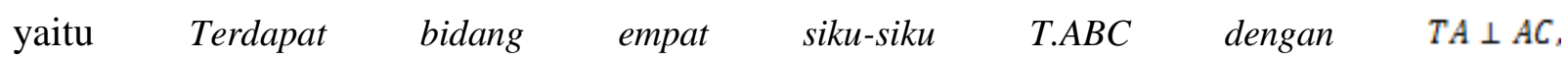
$T A \perp A B, A B \perp A C, A B=A C=\sqrt{2} \mathrm{~cm}$, dan $T A=\sqrt{3} \mathrm{~cm}$. Hitunglah besar sudut antara bidang $T B C$ dan bidang $A B C$ !

Kesulitan pada soal nomor 5 adalah kesulitan yang paling banyak dilakukan siswa. Sehingga persentase tingkat kesulitannya pun paling tinggi. Berikut adalah salah satu contoh kesalahan jawaban siswa pada soal nomor 5 pada gambar 3 . 


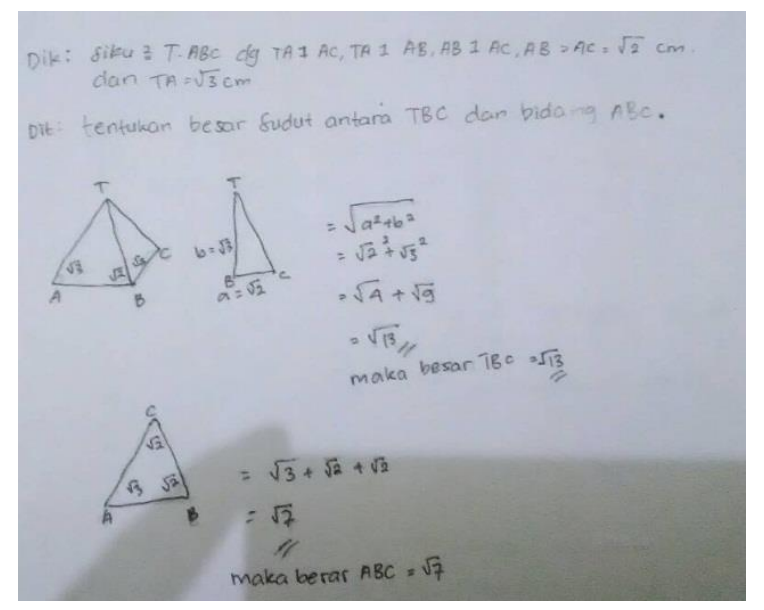

Gambar 3. Kesalahan Jawaban Siswa Soal Nomor 5

Hasil jawaban siswa pada Gambar 3 menunjukkan adanya kesalahan dalam membuat sketsa gambar. Seharusnya titik A dan C disambungkan. Kemudian siswa melakukun perhitungan untuk mencari TB dengan menggunakan teorema pythagoras. Langkah yang dilakukan siswa dalam menentukan panjang TB benar, namun siswa tidak dapat menentukan nilai-nilai yang dianggap perlu untuk mencari besar sudut antara bidang TBC dengan bidang ABC. Siswa justru menentukan luas ABC dengan menggunakan rumus yang salah dan tidak menunjang pada tujuan. Kesalahan yang dilakukan siswa ini menunjukkan bahwa siswa mengalami kesulitan dalam melakukan manipulasi objek matematika yang abstrak. Soal nomor 5 ini menuntut siswa untuk dapat memanipulasi objek matematika yang diketahui dengan mencari hubungan antar konsep dalam mencari jawaban.

Untuk soal lain yaitu nomor 1 dan 4, sebagian besar siswa sudah dapat menjawab dengan benar. Artinya kesulitan yang dialami siswa merupakan kesulitan yang didominasi dari indikator pada soal no 2, 3 dan 5. Sehingga analisis yang dilakukan berfokus pada hasil persentase tingkat kesulitan siswa berpikir abstrak matematika dengan indikator yang telah disajikan pada Tabel 1.

Selain data hasil tes berpikir abstrak matematika, dilakukan juga pemberian angket dan wawancara. Angket digunakan untuk mengetahui faktor-faktor penyebab siswa mengalami kesulitan berpikir abstrak matematika pada materi bangun ruang selama pembelajaran dengan problem posing berkelompok berlangsung. Angket diberikan setelah siswa mengikuti pembelajaran. Berdasarkan hasil angket siswa, diperoleh gambaran terkait faktor-faktor 
kesulitan siswa berpikir abstrak matematika dalam pembelajaran problem posing berkelompok. Hasil analisis dari masing-masing faktor disajikan dalam Tabel 2 berikut.

Tabel 2. Persentase Faktor-Faktor Kesulitan Siswa Berpikir Abstrak Matematika Dalam Pembelajaran Problem Posing Berkelompok

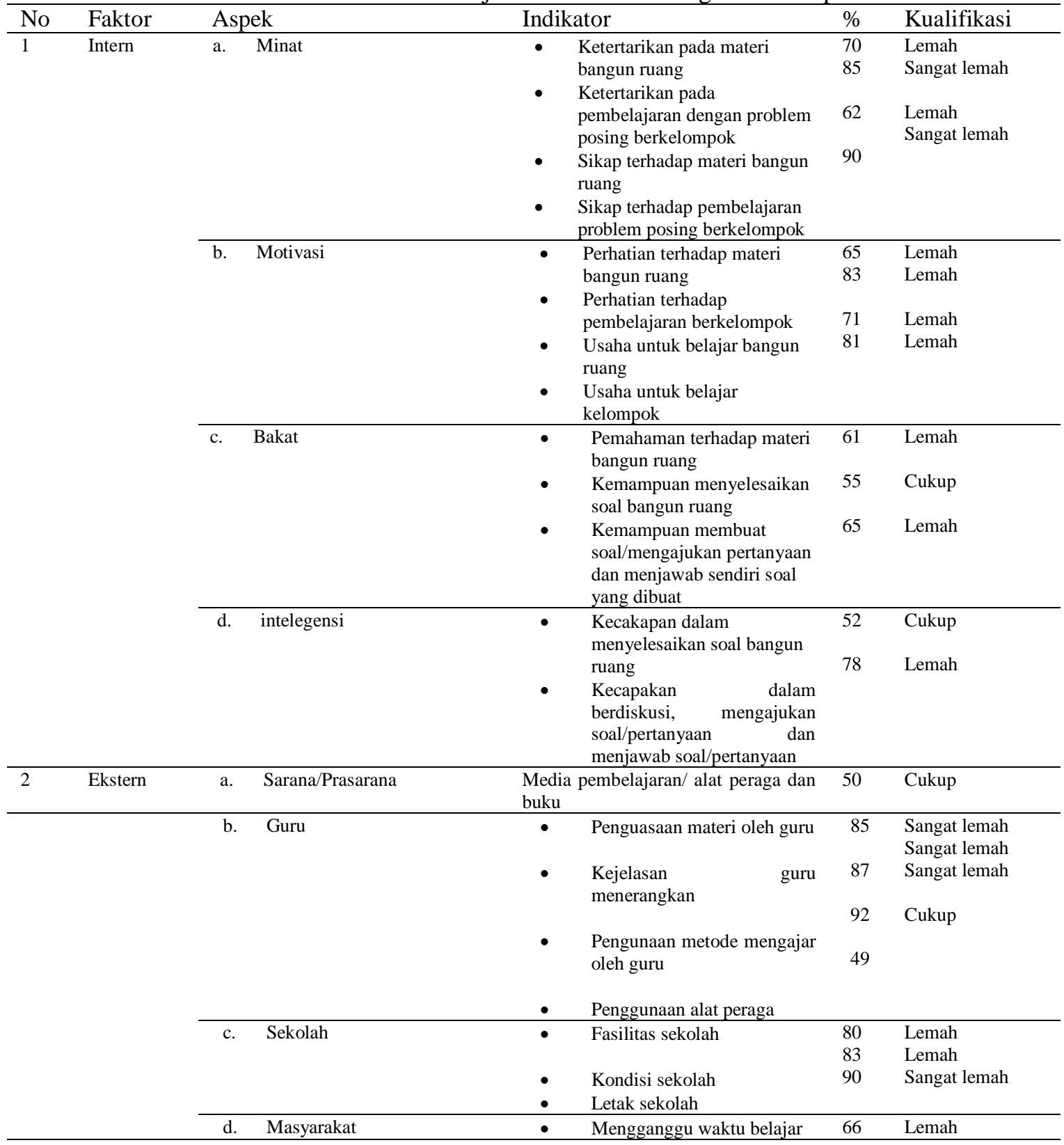

Hasil persentase angket menunjukkan bahwa faktor intern yang berasal dari dalam diri siswa dan eksternal yang berasal dari luar siswa merupakan faktor penyebab kesulitan siswa berpikir abstrak matematika. Faktor internal yang paling besar adalah aspek bakat dengan indikator kemampuan menyelesaikan soal bangun ruang dengan kualifikasi cukup. Artinya 
sebagian besar siswa merasa kurang mampu menyelesaikan soal-soal pada materi bangun ruang. Untuk faktor eksternal yang paling berpengaruh dengan kualifikasi cukup adalah aspek sarana/prasaran yaitu minimnya penggunaan media/alat peraga dalam pembelajaran bangun ruang. Ini berarti penggunaan media/alat peraga dalam pembelajaran belum optimal. Kurang optimalnya penggunaan media/alat peraga ini dikarenakan tidak semua objek pada bangun ruang memiliki media/alat peraga sebagai model pembelajaran dan belum lengkapnya media/alat peraga yang dimiliki sekolah. Sedangkan untuk aspek lainnya, baik faktor intern maupun ekstern berada pada kualifikasi lemah dan sangat lemah. Artinya aspek-aspek selain media/alat peraga dan bakat dianggap tidak terlalu berpengaruh besar terhadap kesulitan siswa berpikir abstrak matematika.

Selanjutnya wawancara digunakan untuk menelusuri kesulitan siswa secara lebih dalam tentang kemampuan abstraksi matematis siswa dalam pembelajaran problem posing berkelompok. Wawancara dilakukan pada 6 orang siswa yang mewakili setiap kelompok grup yang telah dibentuk sebelumnya pada pembelajaran. Data hasil wawancara dengan siswa diperoleh kesimpulan bahwa siswa-siswa tersebut senang dengan pembelajaran problem posing berkelompok. Dengan pembelajaran problem posing berkelompok ini siswa dapat mengembangkan kemampuan diri dalam memanipulasi soal untuk dijadikan sebuah pertanyaan dan menjawab sendiri soal yang telah dibuat sehingga siswa mampu memahami lebih dalam apa yang ditanyakan. Dari hasil wawancara diketahui bahwa kelompok 2 dan 4 masih mengalami kesulitan dalam membuat/mengajukan soal bangun ruang. Akibatnya kelompok tersebut tidak dapat menyelesaikan soal pada tes akhir dan diantaranya bahkan ada yang tidak dapat menjawab soal. Beberapa alasan dikemukakan diantaranya adalah siswa tidak dapat menyelesaikan soal bangun ruang karena mereka tidak secara langsung melihat atau bersentuhan dengan objeknya sehingga siswa mengalami kesulitan dalam membayangkan, menggambarkan dan memanipulasi objek bangun ruang. Alasan lainnya adalah siswa sulit menggambarkan hubungan antar konsep pada bangun ruang sehingga siswa tidak dapat mengaplikasikan konsep pada konteks yang sesuai. Namun pembelajaran dengan metode belajar kelompok dianggap sangat menyenangkan dan dapat meningkatkan pemahaman konsep siswa karena siswa dapat saling bertukar pendapat dalam mempelajari bangun ruang dan saling membantu ketika mengalami kesulitan dalam memahami suatu konsep atau menjawab soal. 
Berdasarkan deskripsi analisis kesulitan siswa dalam mengerjakan soal tes kemampuan abstraksi matematis, analisis angket serta wawancara dengan siswa diketahui bahwa sebagian siswa masih melakukan kesalahan dalam menjawab soal-soal bangun ruang, Ini berarti sebagian siswa masih mengalami kesulitan berpikir abstrak matematika. Hal tersebut sejalan dengan pendapat Buton (Abin 2003) yang menyatakan bahwa dalam mengidentifikasi siswa yang diduga mengalami kesulitan belajar dapat ditunjukkan oleh adanya kegagalan siswa dalam mencapai tujuan-tujuan belajar. Tujuan belajar yang dimaksud adalah kebenaran dalam menjawab soal dan ketercapaian nilai KKM, dimana ketuntasan belajar hanya mencapai $64 \%$. Sehingga dapat dikatakan bahwa keberhasilan belajar belum optimal.

Kesulitan siswa dalam mengerjakan soal kemampuan abstrak matematika diantaranya adalah kesulitan memahami konsep. Kurangnya penguasaan konsep siswa masih terlihat jelas pada hasil jawaban siswa dimana siswa masih belum dapat membuat sketsa bangun ruang dengan benar, padahal membuat sketsa bangun ruang merupakan konsep utama dalam memahami materi bangun ruang. Sketsa bangun ruang ini akan membawa pada pemahaman yang lebih baik karena dengan sketsa siswa dapat menggambarkan keterkaitan antar konsep dan mengaplikasikan konsep secara tepat dalam pemecahan masalah. Zulkardi (2003) menegaskan pentingnya penguasaan konsep dalam pembelajaran matematika. Zulkardi menyatakan bahwa mata pelajaran matematika menekankan pada konsep. Artinya penguasaan konsep manjadi yang paling pertama harus dikuasai siswa untuk dapat menyelesaikan setiap persoalan matematika.

Kesulitan siswa berpikir abstrak matematika lainnya adalah siswa tidak secara langsung melihat atau bersentukan dengan objek bangun ruang. Siswa tidak melakukan pengalaman langsung dengan objek yang menjadi sumber masalah. Hal ini dikarenakan tidak semua konsep bangun ruang dapat dikonkretkan atau secara langsung dibuat media pembelajarannya. Bangun ruang yang sederhana seperti kubus dan balok masih dapat dimodelkan dengan alat peraga, tetapi materi bangun ruang pada kelas $X$ ini adalah bangun ruang pada geometri yang melibatkan titik, garis, sudut dan bidang dalam ruang dimensi tiga sehingga sedikit sekali konsep yang bisa dimodelkan. Kesulitan siswa didasarkan pada abstraknya materi bangun ruang ini juga sesuai dengan hasil wawancara dengan siswa dimana salah satu alasan siswa sulit menyelesaikan soal bangun ruang dikarenakan siswa tidak secara langsung melihat atau bersentuhan dengan objek bangun ruang. 
Kesulitan siswa selanjutnya adalah siswa kurang mampu mengaplikasikan konsep pada konteks yang sesuai dan kesulitan siswa dalam melakukan manipulasi objek matematis yang abstrak. Kesulitan dalam mengaplikasikan konsep dapat dilihat dari hasil jawaban siswa pada soal nomor 3 dimana siswa menggunakan rumus yang tidak sesuai dengan konteks. Kegagalan siswa menjawab soal dengan benar dipengaruhi juga oleh penguasaan konsep. Sebagian besar siswa tidak mengetahui atau hafal rumus-rumus pada bangun ruang, akibatnya siswa tidak dapat mengaplikasikan sebuah konsep yang sesuai dengan apa yang ditanyakan. Kemampuan siswa dalam mengaplikasikan konsep pada konteks yang sesuai adalah kewajiban yang harus dimiliki siswa dalam mengerjakan soal-soal matematika. Hal tersebut menjadi penting karena merupakan bagian dari tujuan umum mempelajari matematika yaitu "memahami konsep matematika, menjelaskan keterkaitan antar konsep dan mengapalikasikan konsep atau logaritma, secara luwes, akurat, efisien dan tepat dalam pemecahan masalah" (Depdiknas, 2006). Selanjutnya kesulitan siswa dalam memanipulasi objek matematis yang abstrak dapat dilihat pada contoh jawaban siswa soal nomor 5. Siswa tidak mampu menentukan sudut antara dua bidang pada bangun ruang. Ketidakmampuan ini menjadikan siswa tidak dapat menentukan konsep-konsep yang menjadi penunjang untuk mendapatkan jawaban yang benar. Sudut antara dua bidang ini dianggap abstrak karena sulit untuk merepresentasikannya dalam dunia nyata. Abstraknya konsep pada bangun ruang ini menyebabkan siswa tidak mampu memvisualisasikan objek matematika. Dalam jurnalnya Pritchard (2012) menyatakan bahwa adanya aspek visualisasi geometri dapat mendorong kemampuan siswa untuk memanipulasi objek geometri yang bersifat abstrak. Jadi, visualisasi sangat penting untuk dapat memanipulasi objek matematika yang abstrak khususnya dalam memahami bangun ruang.

Adapun faktor-faktor yang menyebabkan siswa kesulitan berpikir abstrak matematika berasal dari faktor intern dan faktor ekstern. Berdasarkan persentase faktor kesulitan siswa berpikir abstrak matematika pada Tabel 2, diperoleh gambaran bahwa faktor intern yang paling besar adalah aspek bakat. Siswa masih merasa tidak mampu mengerjakan soal-soal yang berkaitan dengan bangun ruang. Ini artinya kepercayaan diri siswa masih sangat rendah. Kepercayaan diri ini dipengaruhi oleh kesulitan siswa dalam memahami konsep bangun ruang yang bersifat abstrak. Masih banyak siswa yang kebingungan manakala harus membayangkan kemudian menggambarkan setiap objek bangun ruang karena pada dasarnya materi bangun ruang banyak menggunakan visualisasi model matematika yang secara konkret tidak nyata dan 
tidak selalu ada dalam kehidupan sehari-hari. Hal tersebut dapat dipahami karena matematika sendiri merupakan sebuah ilmu dengan objek kajian yang bersifat abstrak (Nurhasanah 2010). Dari hasil wawancara juga diketahui bahwa siswa tidak dapat menyelesaikan soal bangun ruang karena siswa tidak secara langsung melihat atau bersentuhan dengan objeknya sehingga siswa mengalami kesulitan dalam membayangkan, menggambarkan dan memanipulasi objek bangun ruang.

Kesulitan siswa berpikir abstrak dari faktor ekstern didominasi oleh keterbatasan media/alat peraga dalam pembelajaran. Telah dikemukakan sebelumnya dari hasil wawancara bahwa siswa tidak dapat menyelesaikan soal bangun ruang karena siswa tidak secara langsung melihat atau bersentuhan dengan objek bangun ruang. Media/alat peraga bangun ruang sangat penting untuk dapat meminimalisir keabstrakan objek matematika. Menurut Sugiyono (2011) alat peraga adalah suatu perangkat benda konkret yang dirancang, dibuat, dihimpun atau disusun secara sengaja yang digunakan untuk membantu menanamkan atau mengembangkan konsep-konsep maupun prinsip-prinsip dalam matematika. Konsep dan prinsip dalam matematika adalah dasar dalam memahami setiap persoalan matematika. Dengan adanya media/alat peraga diharapkan siswa dapat membangun konsep bangun ruang yang abstrak menjadi lebih nyata sehingga siswa mampu mengaplikasikan konsep tersebut pada konteks yang sesuai. Namun hal tersebut menjadi sesuatu yang sulit dilakukan, mengingat bahwa konsep bangun ruang pada geometri ini melibatkan titik, garis, sudut dan bidang dalam ruang dimensi tiga sehingga sedikit sekali konsep yang bisa dimodelkan atau dibuatkan alat peraga pembelajarannya.

Dalam kaitannya dengan pembelajaran problem posing berkelompok yang digunakan, kesulitan siswa berpikir abstrak matematika dapat diatasi dengan metode pembelajaran yang telah diterapkan. Dengan dibentuknya kelompok belajar, siswa dapat memahami materi bangun ruang dengan lebih baik karena dalam belajar kelompok siswa dapat bertukar pendapat dan saling memperbaiki kesalahan. Melalui pembelajaran problem posing berkelompok juga siswa dapat mengembangkan kemampuan abstraksi matematis karena dalam pembelajaran ini siswa dituntut untuk dapat membuat soal atau mengajukan masalah berkaitan dengan bangun ruang. Kemudian siswa juga harus dapat menjawab soal yang dibuat kelompoknya sendiri maupun soal yang dibuat kelompok lain. Dengan siswa belajar membuat soal atau mengajukan pertanyaan, maka secara tidak langsung siswa harus dapat menguasai konsep bangun ruang, 
belajar membuat sketsa gambar serta belajar membuat soal dari sketsa gambar yang telah dibuat. Aktivitas ini akan memungkinkan siswa mengembangkan kemampuannya dalam berpikir abstrak, menghubungkan konsep-konsep yang saling berkaitan dan akhirnya dapat menyelesaikan persoalan matematika dengan baik dan benar. Hal ini sejalan dengan pernyataan English (Christou, et al. 2005) bahwa problem posing dapat meningkatkan kemampuan berpikir, kemampuan memecahkan masalah, sikap serta kepercayaan diri siswa dalam menyelesaikan masalah dan secara umum berkontribusi terhadap pemahaman konsep matematika.

Berdasarkan analisis data tes kemampuan abstraksi matematis, angket dan wawancara diperoleh kesimpulan bahwa sebagian siswa masih mengalami kesulitan berpikir abstrak matematika setelah pembelajaran problem posing berkelompok. Dari 36 siswa terdapat 13 siswa yang memiliki nilai dibawah KKM, ini menunjukkan bahwa keberhasilan pembelajaran problem posing berkelompok dalam meningkatkan kemampuan abstraksi matematis siswa mencapai 64\%. Capaian belajar tersebut masih dirasa kurang, sehingga diperlukan adanya variasi model pembelajaran yang lebih tepat dalam meningkatkan kemampuan berpikir abstraksi matematis siswa.

\section{KESIMPULAN}

Berdasarkan hasil penelitian dan pembahasan, maka dapat disimpulkan kesulitan siswa berpikir abstrak matematika dalam pembelajaran problem posing berkelompok yaitu siswa kurang penguasaan konsep. Sebagian siswa masih belum dapat membuat sketsa bangun ruang dengan benar, padahal membuat sketsa merupakan konsep utama dalam menyelesaikan persoalan pada bangun ruang. Siswa tidak melakukan pengalaman langsung dengan objek. Hal ini dikarenakan tidak semua konsep pada bangun ruang dapat dikonkretkan atau secara langsung dibuat media pembelajarannya. Siswa kurang mampu mengaplikasikan konsep pada konteks yang sesuai. Sebagian siswa belum dapat menggambarkan keterkaitan antar konsep dan mengaplikasikan konsep secara tepat dalam pemecahan masalah. Siswa mengalami kesulitan dalam memanipulasi objek matematika yang abstrak. Kesulitan ini karena pada dasarnya materi bangun ruang banyak menggunakan visualisasi model matematika yang secara konkret tidak nyata dan tidak selalu ada dalam kehidupan sehari-hari

Adapun faktor-faktor penyebab kesulitan berpikir abstrak matematika dalam pembelajaran problem posing berkelompok berasal dari faktor intern adalah aspek bakat 
dengan indikator kemampuan menyelesaikan soal bangun ruang dengan kualifikasi cukup. Kepercayaan diri siswa masih rendah, siswa masih merasa tidak mampu mengerjakan soalsoal yang berkaitan dengan bangun ruang dan faktor ekstern adalah aspek sarana/prasarana yaitu minimnya penggunaan media/alat peraga dalam pembelajaran bangun ruang dengan kualifikasi cukup. Faktor media/alat peraga menjadi faktor penyebab paling tinggi siswa mengalami kesulitan berpikir abstrak matematika.

\section{REKOMENDASI}

Berdasarkan simpulan penelitian di atas, dapat diketengahkan beberapa saran, yaitu hasil penelitian menunjukkan bahwa sebagian siswa masih kesulitan berpikir abstrak matematika dengan pembelajaran problem posing berkelompok yang diterapkan. Dengan demikian disarankan untuk menggunakan model pembelajaran lain untuk lebih mengatasi kesulitan siswa berpikir abstrak matematika pada materi bangun ruang dan minimnya media/alat peraga yang digunakan dalam pembelajaran, menjadi faktor penyebab utama siswa kesulitan berpikir abstrak matematika. Sehingga diharapkan bagi peneliti selanjutnya untuk dapat mengembangkan media/alat peraga dalam mengatasi kesulitan siswa berpikir abstrak matematika pada materi bangun ruang.

\section{REFERENSI}

Abin, S. (2003). Psikologi Pendidikan. Bandung: PT. Remaja Rosda Karya

Christou, C., Mousoulides, N., Pittalis, M., Pantazi, D.P., \& Sriraman, B. (2005). An Empirical Taxonomy of Problem Posing Processes. Zentralblatt für Didaktik der Mathematik (ZDM) - The International Journal on Mathematics Education. 37(3) (Online), (http://subs.emis.de/journals/ZDM/zdm053a4.pdf, diakses 25 November 2016)

Depdiknas. (2006). Peraturan Pemerintah No 22 Tahun 2006 Tentang Standar Isi Kurikulum Tingkat Satuan Pendidikan Mata Pelajaran Matematika SD dan Madrasyah Ibtidayah (MI). Jakarta: Depdiknas

Kilpatrick, J., Swafford, J., dan Findell, B. (2001). Adding it up: Helping children Mathematics. Washington, DC: National Academy Press 
Mukhtar. (2013). Peningkatan kemampuan Abstraksi Dan Generalisasi Matematis Siswa Sekolah Menengah Pertama Melalui Pembelajaran Dengan Pendekatan Metaphorical Thinking. Bandung: Universitas Pendidikan Indonesia

Nurhasanah, F. (2010). Abstraksi Siswa SMP dalam Belajar Geometri melalui Penerapan Model Van Hiele dan Geometers' Sketchpad (Junior High School Student' Abstraction in learning Geometry Through Van Hiele's Model and Geometers' Sketchpad). Bandung: Universitas Pendidikan Indonesia

Pritchard, C. K., \& Lamb, J. H. (2012). Teaching Geometry to Visually Impaired Students. The Mathematics Teacher, 106(1), 22-27.

Sugiyono. (2011). Alat Peraga dalam Pembelajaran Matematika. Kec. Trincing, Secang, Jateng: Makalah disampaikan pada pelatihan Materi matematika KKG MI Kec. Trincing, Secang, Jateng tanggal 20 Juli 2011

Sumarmo, U. (2010). Berpikir dan Disposisi Matematik: Apa, Mengapa, dan Bagaimana Dikembangkan pada Peserta Didik. Artikel pada FPMIPA UPI Bandung.

Zulkardi. (2003). Pendidikan Matematika Republik Indonesia. http://pmri.or.id diakses tanggal 18 November 2016

Upu, H. (2003). Problem Posing dan Problem Solving Dalam Pembelajaran Matematika. Bandung: Pustaka Ramadhan 
